\title{
Bringing Adam Smith's pin factory to life: Field trips and discussions as forms of experiential learning
}

\begin{abstract}
Monica Galizzi ${ }^{1}$
Abstract: Educators are often aware of the need to implement a variety of teaching techniques to reach out to students with different learning styles. I describe an attempt to target multimodal learners by bringing classical economic texts and concepts to life through discussions, field visits and role playing exercises.

In my Labor Economics class, I analyze the relationship existing between demand for labor, technological advances, and trade. As a foundation for such analysis, I assign the reading of Adam Smith's The Wealth of Nations chapters regarding the division of labor. To increase students' interest toward the topics, I precede the text discussion with a field visit to a museum of industrial revolution. Here students are asked to participate also as "factory workers" to an assembly line exercise that brings Smith's description of a pin factory to life. They are then asked to reflect on this experience and to use it as a foundation to inform the following class discussions about Smith's chapters.

In this paper, I describe the main learning and retention objectives of this exercise, its implementation, challenges, and students' learning outcomes and feedback about enjoyment and recollection. Field trip participants performed significantly better when tested on the relevant concepts. I also discuss the rewards and institutional challenges associated with making use of community resources to increase the understanding of the concrete applications of the economics concept we teach.
\end{abstract}

Keywords: experiential learning, field visits, discussions, learning styles, VARK, Adam Smith, economics

\section{Introduction}

A rich body of research has provided evidence that individuals differ in terms of how they prefer information to be presented to them. They also differ in terms of their aptitudes for thinking and processing such information (Pahsler et al., 2009). The education literature has produced several different frameworks to categorize and analyze different learning styles among individuals (Nilson, 2003). Empirical studies have also tested the hypothesis that teachers and students often learn in different ways and that such discrepancy may affects students' education and performance (Boatman et al., 2008; Charkins et al., 1985; Borg \& Stranahan, 2002; Lopus \& Hoff, 2009). This discrepancy is likely to be greater in higher education because academicians are more likely to fall under the category of "assimilators:" those who "combine abstract conceptualization and reflective observation into a style that excels at organization and synthesis. ... [These] individuals focus on abstract ideas and concepts rather than people or practical

\footnotetext{
${ }^{1}$ Professor of Economics, University of Massachusetts Lowell, monica_galizzi@uml.edu
} 
applications" (Nilson, 2003, p. 81). These pieces of evidence have led to the hypothesis that individuals learn better when taught in a style that matches their preferences. The testing of such hypothesis has often been unsatisfactory, however (Pashler et al., 2009).

Economists have shown certain inertia in questioning their teaching effectiveness and in developing teaching methods that deviate from traditional lectures (Watts \& Becker, 2008). Thanks to initiatives such as the Teaching Innovation Program ${ }^{2}$, however, economics instructors are becoming aware of the need to target students' different learning styles through more active teaching techniques (Salemi, 2002). There is still very little evidence, however, about the predominant learning style of students enrolled in economics classes. We also know very little about the relationship between their learning preferences, teaching techniques and learning outcomes. Therefore, in this paper I describe an attempt to assess a teaching method that combines abstract thinking (the careful and inquisitive reading of a text through an organized class discussion) with a rarely studied type of experiential learning: field visits. I analyze grades and feedback from students in an upper level Labor Economics class to address the following questions:

- Which learning preferences do characterize economics students? Do they justify the effort of introducing different teaching techniques?

- What was the effect on students' learning of combining class discussion of a classical text with a field trip?

- What was the evidence on memory and satisfaction of combining discussion with a field trip?

- What are the recommendations for instructors who want to implement this type of teaching techniques?

Although the experience described here refers to a specific economic topic and to a specific location, it suggests a way to exploit local resources (such as firms, public agencies, museums, public projects) to achieve learning objectives through the combination of experiential learning activities and readings. It is an attempt to reach out to students with different learning preferences.

\section{Literature Review}

\section{Learning preferences among economics students}

We have very limited evidence regarding the effect of different learning styles on economics learning. The majority of research on this topic has used personality assessments (such as the Myers-Briggs Type Indicator) to predict the relationship between personality types and class performance (Borg \& Stranahan, 2002; Emerson \& Taylor, 2007). In these studies personality traits are used to deduce learning styles. Learning styles can be evaluated through more specific instruments, however, such as the VARK Questionnaire (Fleming \& Mills, 1992). This tool assesses how individuals gather, organize, and think about information to categorize their learning preferences. It identifies four types of learners: visual (who prefer diagrams, graphs, charts), aural (who prefer debates, discussions, story telling, videos plus audio), $\mathrm{read} / \mathrm{write}$ (who prefer texts, readings, essays), and kinesthetic (who like field trips, labs, hands

\footnotetext{
${ }^{2}$ The program was sponsored by the Committee on Economic Education of the American Economic Association and was funded by National Science Foundation. It ran from 2005 to 2009 (www.vanderbilt.edu/AEA/AEACEE/TIP.htm)
} 
on activities, role play). The VARK is the only learning styles questionnaire that identifies separately the read/write and kinesthetic categories (Hawk \& Shah, 2007) because it focuses on sensory preferences.

According to the VARK's results, individuals can either be identified as unimodal because they belong to only one of the four categories of learning - or as multimodal. In the last case, students have either any combination of two or three strong learning preferences, or have preferences that are evenly split among the four categories. They are students who choose a different mode of learning depending on the occasion, or who need to have the information processed in several ways before fully understanding it.

Only very few studies have reported results about the VARK questionnaire by focusing exclusively on economics and management classes. They have typically studied undergraduate classes in Principles of Micro or Macroeconomics (Durham et al., 2007; Bhadra, 2006; Bhaskar, 2011; Harmon et al., 2014; Leung et al., 2013). No study has specifically looked at differences across students' majors within such introductory classes but the majority of students examined were economics or business majors. Only two studies have focused on MBA students (Alexandra \& Georgeta, 2011; Fitkov-Norris \& Yeghiazarian, 2013). Overall these analyses have found that the majority of undergraduate students surveyed are multimodal learners with percentages ranging from $68 \%$ to $75 \%$ of the total classes enrollment; kinesthetic and aural learners are found to be the most frequent unimodal categories. No gender differences have been found (Bhaskar, 2011; Fitkov-Norris \&Yeghiazarian, 2013).

Interestingly, across all these studies, visual learners are the smallest category of students. However, Boatman et al. (2008) found that the VARK visual learners are exactly those students who perform significantly better in introductory economic classes. This is not surprising given that economics teaching relies on strong visual presentation through the use of graphs and charts. But these results challenge economic instructors to reflect on whether their traditional teaching methods are the best suited to teach economic literacy to the greatest number of students. Indeed, the limited but consistent evidence about the predominance of multimodal, kinesthetic or aural students in introductory economic classes suggests the need to introduce a variety of teaching techniques, including experiential techniques.

\section{Experiential learning in economics classes}

Experiential learning occurs when students are asked to participate in concrete experiences that apply directly to the concepts they are studying. In fact, in the often cited conceptualization offered by Kolb (1984), experiential learning starts with a concrete experience that is followed first by observation and reflection, second by abstract conceptualization, and concludes with the testing of the developed concepts in new situations. Experiential learning produces several benefits: concrete experiences awaken emotions and often involve not only intellectual but full body participation. Such experiences have been found to affect memory more deeply and therefore to increase retention of knowledge. Concrete experiences that involve working with a group of peers or with the instructor are also more pleasant and help to develop stronger bonding among participants. This leads to higher motivation and greater appreciation of the learning experience (Spencer \& Van Eynde, 1986; Hawtrey, 2007; Lawson, 2007).

Economists are becoming increasingly familiar with the introduction of experiments in principles or upper level classes as a form to experiential learning. Recent studies have shown that such experimental approach leads to better learning in terms of higher test scores (Emerson 
\& Taylor, 2004; Dickie, 2006). Very few studies have explored the effectiveness of experiments across individuals with different personality types or learning preferences, however. Their main findings indicate that experiments are beneficial overall although the magnitude of the benefit may vary depending on whether individuals are more or less abstract thinkers (Emerson \& Taylor, 2007) or kinesthetic learners (Durham et al., 2007), possibly because during experiments students act both as participants and observers. Some evidence suggests that experiments also improve attitudes toward economics and retention of economic concepts (Durham et al., 2007\& Garces-Ozanne \& Esplin, 2010).

Class discussions or case studies are also a type of successful experiential learning (Jensen \& Owen, 2003). They stimulate students by making them participants in the creation of knowledge, but they have been found to be teaching methods that are challenging for students whose learning style is more concrete than abstract, or for students with weak reading comprehension skills (Madden, 2010). These students may be better served by class experiments, service learning, or by a rarely studied type of experiential learning: field visits.

Field trips are one of the teaching techniques that together with role play and research projects work best for those students who are characterized by a kinesthetic learning style, i.e. who learn the most "by doing" (Fleming \& Mills, 1992). Furthermore, field trips are one of the experiential learning activities that have been found to be beneficial for almost all categories of "learning types" -- with the exception of the above cited "assimilators" who prefer to learn by listening and reading on their own (Nilson, 2003). However, most of the literature on field trips has focused on K-12 education or on college level science classes (Smith, 2007). There is very little evidence about the challenges and effectiveness of conducting field visits in economic classes (Lempert, 1996; Bixler \& Squires, 1998). Smith (2007) represents the only recent study on the topic where the author acknowledges the difficulty of collecting data to test the efficiency of field trips. He concludes, however, that field trips generate enthusiasm in the subject learned and that they lead students to learn the complexity of real world issues and to develop social capital.

\section{Class Design and Objectives}

During the first day of my Labor Economics class I always ask my students to write down some of the topics they would like to be addressed during the course of the semester. Some of the common recurrent themes are their job prospects as college graduates, the impact of offshoring and immigration on U.S. workers, and the impact of unions on the labor market. Finally, possibly because often at least one third of the students enrolled in the class often come from the School of Engineering, another common theme is the impact of emerging technologies on students' future jobs ${ }^{3}$. Therefore, to capitalize on students' initial interest and to demonstrate a willingness to respond to their requests, I have decided to make the relationship between demand for labor, technological advances, and trade one of the first topics analyzed during the second week of class. However, given that many of the analytical tools needed to study these topics formally are developed later during the course of the semester, the analysis of these themes starts with different activities that complement each other and attempt to reach out to different learning styles.

\footnotetext{
${ }^{3}$ The class only requires Principles of Microeconomics as a prerequisite.
} 


\section{Readings}

Students were asked to read the first three chapters of Adam Smith's The Wealth of Nations. Written in 1776, this book is often regarded as the seminal work that started economics as a social science. Its first three chapters are dedicated to the analysis of the causes and advantages of the division of labor. They include the famous example of the pin factory where Smith describes the remarkable increase in final output that could be achieved when factories implemented new technologies where each worker specialized on a single task (http://www.econlib.org/library/Smith/smWN1.html\#B.I, Ch.1, Of the Division of Labor.)

Previous experience has shown me that typically many of the students respond with skepticism to the idea of reading and analyzing classical texts. They expect an economic history lesson which they think could be boring or difficult because of the "old style English." Therefore, to increase these students' interest in the topics concerned, I decided to assign not only the reading of Smith's text but to bring the students to visit a museum of the industrial revolution and to follow it with a class discussion.

\section{Field Trip}

The Boott Cotton Mills Museum is dedicated to celebrating the "birthplace of America's industrial revolution". It is located in Lowell, Massachusetts, not far from the University. In the late eighteenth century the city of Lowell witnessed an explosion of new industrial activities. Because of its location (30 miles from Boston and the Atlantic Ocean) situated on the Merrimack River with a dam to harness its energy, Lowell became the chosen site for entrepreneurs who developed an extensive system of canals and textile mills (http://www.nps.gov/lowe/photosmultimedia/seeds_of_industry.htm).

Before the visit to the museum I discussed with the museum staff the main learning outcomes I hoped my students would achieve with this field trip: an understanding of the relationship between division of labor and opportunities to trade; of the role played by a location demographic and geographic characteristic in affecting trade; of the direction of causality existing between new technologies and division of labor (see Appendix I). Accordingly, during the museum visit my students were first guided by a park ranger who showed them how new loom technology had developed and improved over time; how the geography of Lowell had been conducive to the development of the textile industry; how different waves of workers (first girls from the surrounding countryside and then immigrants from different ethnic groups) had been hired to carry out new and different tasks; and how the history of the mills and their workers was affected by increased competition and changes in political scenarios and in technologies affecting production costs (such as the anti-slavery movement that threatened to lead to a higher cost for cotton or the arrival of new waves of immigrants or the introduction of new labor saving machines). The students were then taken into an operating mill to observe both the loom technology in action, the interaction between machines and workers (enacted by park staff), and the working conditions that were typical of a nineteenth century mill.

\section{Hands-on Activity}

The museum visit concluded with a role playing exercise. Make believe scenarios where students are asked to act and identify with the roles they are assigned are one of the 
recommended experiential learning teaching methods (Nilson, 2003). At the museum, students were asked to assume the role of "factory workers" in an assembly line exercise that brought Smith's description of a pin factory to life: under the eyes of a supervisor, students became mill print design workers and were sent in groups to four assembly lines to produce paper "towels" (Tsongas Industrial History Center, 2011; Smith \& O'Connell, 1997). Along the assembly lines each student had to choose to perform one of the following tasks: rolling, printing, cutting, and assessing the quality of the work. In a simulation of the effect of strikes or of layoffs to reduce costs, students were then randomly removed from the assembly line; the ones remaining had to adjust to performing the tasks left uncovered under the same original time pressure with evident consequences including the decline of product quality and the increase in worker stress (or, in the case of my class, increase in students' hilarity). The exercise ended with a Q \& A session in which students raised questions about working conditions, the complementarity and substitution of machines and labor, the role of immigrant and women workers, and the rise and actions of unions. Some students also observed how the "pretend assembly lines" could be used to illustrate the law of diminishing marginal product that they had previously studied in their Principles of Microeconomics course and had just reviewed in the beginning classes of the Labor Economics course.

\section{Class Discussion}

During the first class after the field trip students were asked to participate in a formal in class discussion about Smith's chapters. In this context, discussion is defined by Salemi as "inquiry into the meaning of a text that students and instructors have read and thought about earlier". He goes on to say, "In my model the discussion leader has carefully prepared discussion questions and distributed them in advance. In my model, the discussion leader serves as facilitator rather than as participant during discussion" (Salemi, 2005, p. 3). To prepare for the discussion, students had been required to submit a brief written summary of the reading before the beginning of the class. Appendix 1 illustrates the different questions given to students to guide the class discussion ${ }^{4}$. The original learning objectives had been designed to be specific enough so that the targeted learning outcomes could be observed during the class discussion. Both the interpretative, and supporting questions ${ }^{5}$, had been specifically written with the goal of encouraging reflection on the connections between what the students had read and what they had learned from the museum tour and the "workers on the line" role playing exercise. Finally, the concluding questions were written with the aim of leading students through the fourth and final step of Kolb's experiential learning model: to "test the implications of concepts in new situations" (Spencer \& Van Eynde, 1986). The questions asked students to further reflect on what they had read and absorbed during the field visit; each student was asked to describe the lessons that classical economic texts and economic history provide to better understand their own current and future economic environment.

\footnotetext{
${ }^{4}$ This discussion module was prepared under the supervision of Professor Michael Salemi to satisfy the requirements of Phase II of the Teaching Innovation Program (TIP).

${ }^{5}$ As described in Hansen and Salemi (1998) the interpretative questions challenge the students to identify the main messages of an author's writing while supporting questions are prepared by the instructor to assist students in their quest. Concluding questions ask students to summarize their learning and, possibly, to relate such learning to their experiences.
} 


\section{"Belonging"}

The decision to combine readings with a formal class discussion and a field trip aimed at achieving the learning objectives among students with different learning styles. It had a secondary goal, however: to create stronger bonding among the students and with the teacher in order to facilitate future work during the semester. My undergraduates attend a large urban public university and even for this type of students social integration has been found to be a more important factor in predicting retention than financial considerations (Wetzel et al., 1999). In fact, many of my students live off campus and commute (65\%). Furthermore, a survey I implement among my students at the beginning of each semester shows that typically the majority of students attending the Labor Economics class are enrolled full-time but also work at least 20 (and frequently 35) hours per week. These students are therefore much pressured for time and have few opportunities to socialize and get to know each other. So, while class time often constitutes the main learning component of the students' college experience, the class atmosphere lacks collegiality. This is not conducive to an optimal learning environment given the new research showing how social interaction is a key determinant of learning (Meltzoff et al., 2009). Furthermore, rich evidence documents that not only the quality of academic experience but also feeling of "belonging" and perceptions of the institution's concern are among the main determinants of students' satisfaction (Gibson, 2010). Therefore, in this context, an additional aim of both the carefully organized class discussion in groups and the field visit was to help students develop better personal and learning relationships with their peers and with their teacher. These are also key objectives for an instructor given the need to increase students' retention.

\section{Results}

I conducted the described class activity during three different academic years. The average class size was 27 students. Most of the results presented here refer to all students' exam performances as well as to answers that over three years a total of 77 students gave to a survey administered at the end of each semester (a 94\% response rate). Students were guaranteed that their answers were not identifiable and that the questionnaires were going to be submitted to the instructor only after the final grades had been assigned.

\section{Students learning preferences}

The students' survey included several questions regarding the "reading-discussion-field trip" class exercise. The version of the survey administered in the last survey year included also a link to the VARK questionnaire, Version 7.1 (http://www.varklearn.com/english/page.asp? $p=q u e s t i o n n a i r e)$. Students were asked to answer such questionnaire and to report their finale scores. Out of the 23 students who did so, $74 \%$ were characterized by a multimodal preferences (35\% four modal, $13 \%$ three modal, $26 \%$ bi modal) and $26 \%$ had a single preference ( $0 \%$ visual, $4 \%$ aural, $13 \% \mathrm{read} /$ write, $9 \%$ kinesthetic). These results are consistent with what had been found in the other studies reviewed above. They reveal the prevalence of students who are multimodal in their learning preferences and that the single visual mode of learning is the least represented. This happened despite the fact that half of the students 
in the class majored in economics with the remaining students usually being business or engineering majors.

The students' survey permitted to cast additional light about students' interests and preferences. For example, both the class discussion and the field trip (Table 1) were found to be much more interesting activities than the simple reading of the text ( $89 \%$ and $90 \%$ vs. $79 \%$ ). The differences were statistically significant ( $\mathrm{p}$-value $=0.02$ ). In addition, $64 \%$ of students reported that they would like more hands on activities in their economic classes, $52 \%$ would like more field visits and $36 \%$ more guided class discussions.

Table 1

Summary of students' feedback about different learning activities

\begin{tabular}{|c|c|c|c|}
\hline & $\begin{array}{l}\text { Did you find the } \\
\text { interesting? }\end{array}$ & $\begin{array}{l}\text { Did the } \quad \text { help } \\
\text { you understand } \\
\text { the readings } \\
\text { better? }\end{array}$ & $\begin{array}{l}\text { In your economic } \\
\text { classes, would } \\
\text { you like more_? }\end{array}$ \\
\hline \multicolumn{4}{|l|}{$\begin{array}{l}\text { Reading of } \\
\text { Smith's chapters }\end{array}$} \\
\hline Yes & $79 \%$ & & \\
\hline No & $12 \%$ & & \\
\hline Indifferent & $9 \%$ & & \\
\hline \multicolumn{4}{|l|}{ Class discussion } \\
\hline Yes & $89 \%$ & $75 \%$ & $36 \%$ \\
\hline No & $4 \%$ & $3 \%$ & $16 \%$ \\
\hline Indifferent & $7 \%$ & $22 \%$ & $48 \%$ \\
\hline \multicolumn{4}{|l|}{ Field trip } \\
\hline Yes & $90 \%$ & $79 \%$ & $52 \%$ \\
\hline No & $7 \%$ & $10 \%$ & $16 \%$ \\
\hline Indifferent & $2 \%$ & $12 \%$ & $36 \%$ \\
\hline \multicolumn{4}{|l|}{ Hands on activity } \\
\hline Yes & $86 \%$ & & $64 \%$ \\
\hline No & $14 \%$ & & $0 \%$ \\
\hline Indifferent & $0 \%$ & & $36 \%$ \\
\hline
\end{tabular}

\section{Students' performance}

Ideally, to assess the effectiveness of the field trip experience we should conduct a control experiment by breaking students into different groups by learning preferences. Then, we should randomly assign some students to the field trip group exercise and others to a group that is exposed only to the reading and the class discussion (Pashler et al., 2009). In this case, the 
small class size, the constraints on students' schedule, and the large majority of students with multimodal learning preferences precluded this approach. Therefore, to assess the impact of this class activity, I looked simply at the score students received in the specific exam question that asked them to reflect on the Smith's chapter (Appendix I). I tested for differences in scores between the students who had attended the field trip (average score of 6.5 out of 10 points) and the one who had not (average score of 5.2). In fact every year around $40 \%$ of the students cannot participate to the school trip because of conflicts with other classes or because of jobs obligations. These students are then required to familiarize themselves with the museum through its website. This information contains very detailed images and text.

Because students were not randomly assigned to the two groups, however, it is possible that potential differences in average scores were caused by other factors. For example, it may be reasonable to expect that students who do not attend the trip will perform less well simply because working students have less time to study and prepare for exams. Therefore to isolate the effect of the field trip, I compared the scores of the two groups also in the overall exam (made of multiple choice and four additional problems and essay questions). Results of a test for equality of means indicated that the field trip group obtained a significantly different score in the Smith's reading questions $(p$-value $=0.04)$. At the same time there were not significant differences in the overall test performances across the two groups $(p$-value $=0.85)$. This suggests that the field trip experience did positively affect students' achievement of the learning objectives.

The survey results also gave some insights about the process and the outcome of students' learning. Students found the discussion and the field trip equally useful $(75 \%$ and $79 \%)$ in helping with the understanding of the reading (Table 1), although a more detailed survey answers revealed that the discussion was more useful in understanding the relationship between opportunities to trade and division of labor, while the field trip gave more insights about the relationship between opportunities to trade and geographical characteristics. Half the students had very low learning expectations when they were first asked to read Smith's chapters. Qualitative answers indicate that eventually, however, the large majority of students were surprised to find the reading of interest with only a few dissenting voices that found them not very relevant:

"I was expecting old ideas that don't apply anymore, but I was wrong. It was very interesting."

"It was interesting because what he stated seems so obvious after you read it, but you probably would never have thought about it unless it had been pointed out to you."

"I had never heard of Adam Smith."

"I have heard a lot about Smith, being an Econ major, but I have never read any of his work until now. I had expected it to be somewhat dry and boring but that was not the case."

"I was surprised how an economics paper written almost 250 years ago could be so relevant to today's markets. It seemed to make perfect sense."

"I actually really enjoyed the Adam Smith reading and thought it was one of the most interesting aspects of the class this semester."

"The concepts were more helpful than I thought because they apply to many other theories we discussed later in class."

"I found the material to be a challenging read but I really enjoyed the concepts."

"Very annoying to read and seemed like very simple concepts stretched out into 20 more pages than necessary." 
When asked which concepts they remembered about the reading and the discussion that had happened three months before, they recalled very easily the role played by division of labor, technology, trade and geography in determining economic growth:

"How division of labor makes working processes much more efficient. If a market is near water it's also helpful in order to promote trade. Technology in an import factor for growth and success."

"Division of labor, especially the comparison between rich and poor countries."

"Division of labor, importance of rivers, effect of division of labor in both academic and trade fields, division of labor occurs in areas with greater populations and within fields that are more in demand."

"How the market size affects the division of labor and how division of labor improves an employee's dexterity and saves time to produce more things."

They commented also about other insights they gained from the field visit and the workers' on the line activity. What they gained went beyond a better understanding of Smith's chapters. They gained insights about the economic concepts of economies to scale, of substitution effect, of general versus job specific training:

"Helped with the concept of how location matters."

"It helped me understand that in a more productive society, tasks are more specialized."

"It seemed that the role of technology changed: the mill girls did not require specialized training and workers skills were not valued, leaving them victim to poor working conditions."

"The introduction of new technologies leading to economies of scale."

"As Adam Smith stated specialization leads to division of labor but it has its limitations and it can be seen in what happened at the mills. Division of labor combined with technologies led to a substitution effect that caused mill owners to undermine and underpay workers."

"It taught us that if you were one of those at the bottom, you would never see the final product which leads to feeling unimportant and sadness."

"Gender roles."

"Unions and their initial necessity."

"Urban migration."

"They hired immigrants and separated people so they couldn't talk to each other."

"The setting, the machinery, the technology --it brought you back in time to a completely different way of production."

"It was great to see that the more workers you get on one single line of work, you might hurt productivity... the law of diminishing marginal return."

"Surprisingly most that we've covered are still very fresh. I have been able to apply it to Macro Theory which I am currently taking."

\section{Students' retention of economic concepts and satisfaction}

Figure 1 illustrates students' answers about the value that they attributed to the different components of the class activity. While class discussion was considered the most useful technique to learn economic concepts, the hands on activity was considered the best tool to remember such concepts while the field trip was considered the activity students enjoyed the 
most. However, Fisher's exact tests found that these three activities were scored with statistically significant different values only in terms of their contribution to learning ( $p$ value $=0.00$ ) and to remembering concepts ( $p$-value $=0.00)$, but not to enjoying classes ( $p$ value $=0.7$ ).

It is important to recall that students undertook these activities in a precise sequence (reading, field visit, hands on exercise and, finally, guided class discussion). Therefore it is possible that their evaluations of the last activities were affected by the exposure to the previous ones. Therefore the qualitative results are useful again to provide additional insights about students' reasoning.

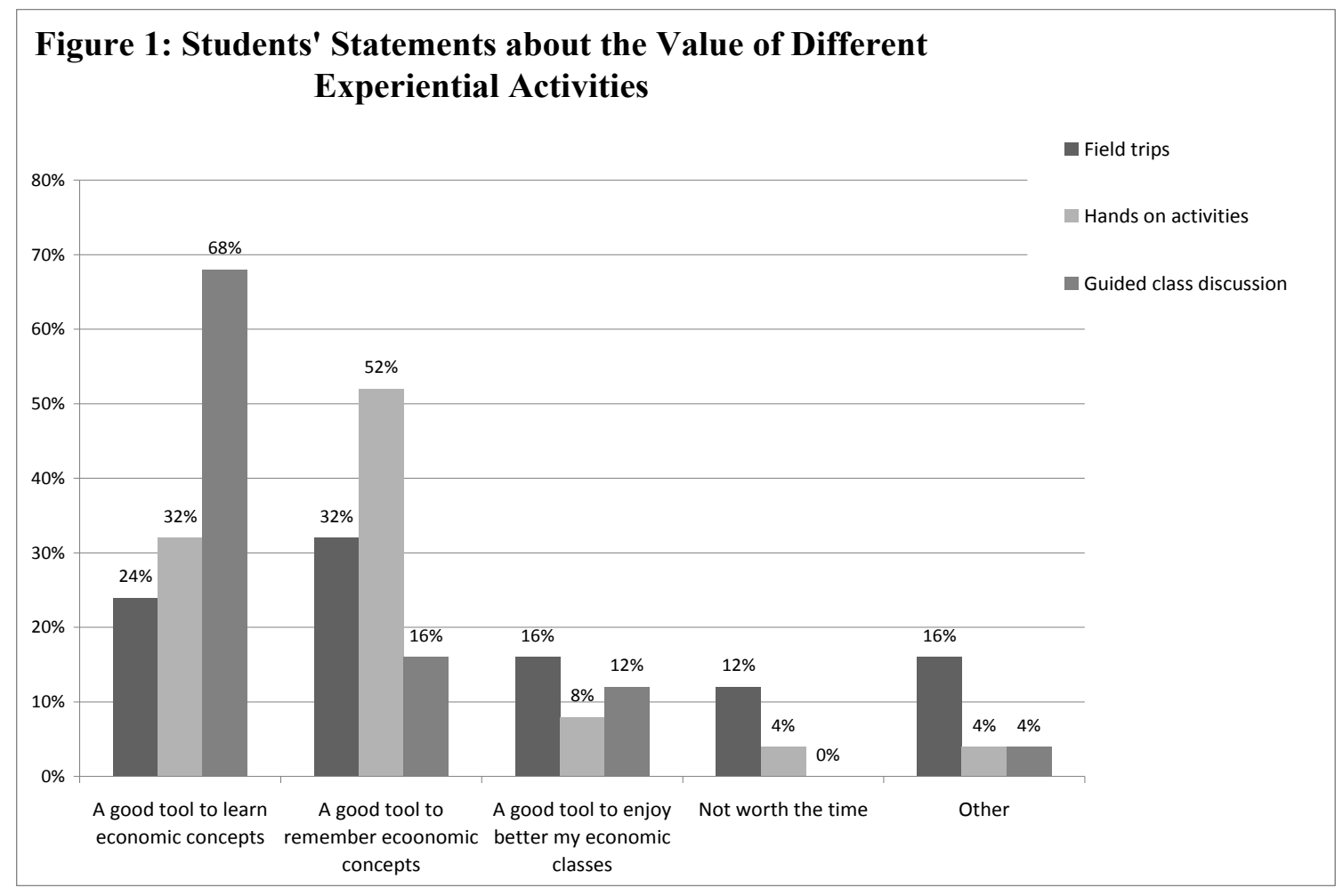

The large majority of students stated that the class discussion had helped them to understand better the reading because the guided questions and the peer exchanges increased their understanding of a somehow difficult material:

"For some reason I follow along better when I have questions that I know I have to answer. It helps force understanding"

"Having a system of feedback, like a class discussion is my preferred way to review material."

"The material was not an easy read so the discussion helped to elaborate on key points."

Twenty five percent of students replied that the most interesting part of the class discussion had been the opportunity to interact with classmates because the diversity of skills and opinions further facilitated the learning:

"There are people who better understood the reading and could restate the ideas in the words of a student." 
"It made the concepts easier to understand. It's nice to discuss theories with the class making it a more dynamic class room. This helps everyone in the class."

"It was great having my classmates' opinions and perspectives, it made me learn or focus on something that I hadn't before."

There were only very few dissenting voices for whom reading was sufficient for learning. They revealed "assimilators" who lamented the fact that the discussion had happened at the expenses of time that could have been spend teaching additional new material:

"I spent a long time on the reading and feel like I got mostly everything through reading."

"I don't feel I learn anything from a class discussion. It just takes up time and therefore limits the amount of material to be covered."

Students commented also about whether and why they enjoyed the museum visit. They specifically stated that this activity had awakened their sight and hearing senses and therefore improved their learning and alertness:

"This was one of the important trips I have ever attended. I learned by just looking and listening from the guide or instructor when they explained everything."

"They create real world examples. It's an easier connection."

"I liked the activity we did, where we were placed in a situation that is reminiscent of how a factory worker's might have been and made me understand the pressure they must have been under working the machines."

"Field trips make the class more interesting and as a result are better at keeping the students in the class a captive audience."

"It was nice to have class in a different location not sitting at a desk the whole time."

However, several students expressed the difficulties associated with this type of class activity because it is more time consuming than a typical class. This may become a real obstacle when students have to juggle other classes or job duties:

"Though the trip is educational, reworking a schedule for a commuter who works four days a week is difficult."

"Hard time balancing time for field trips and other classes and work."

Students' answers clearly indicated how role playing/hands on activities affected the ability to retain what they leaned in class depending on their learning preferences. Their answers were particularly revealing because they were consistent with my finding that the majority of my students were multimodal learners. They commented very clearly how this sensory experience was not only enjoyable but also lead to almost involuntary learning and greater learning retention:

"Hands on activities make things easier to understand. It is also fun and doesn't feel like you are 'learning."

"Hands-on activities last longer in my memory, and make the class more entertaining."

"It always helps to see a written concept unfold in reality, makes it more believable/memorable."

"Most of information can be found in online or brochure, but the activity gave more idea about how hard it was at the factory for real."

"It helps form independent thought."

"I feel hands on activities with the lectures cement what we learn better and helps us retain it better."

Only very few answers revealed dissatisfaction with this class experience. They were also very interesting, however, because they explicitly revealed again how they belonged to 
"assimilator" students who were very comfortable with learning simply thought reading or traditional lectures:

"I am a person who learns in a very traditional manner. Notes and readings work very well for me but if it works for others I can learn that way also."

"It's hard to think of beneficial activities over some lectures or discussion."

"I feel comfortable with material presented, and the examples given seen good enough to grasp concepts."

Finally, students' feedback confirmed that field visit and hands on group activity have the additional benefit of involving all students, even the ones who are uncomfortable with traditional class participation. They produce a camaraderie that makes the experience more pleasant and, therefore, facilitates learning:

"Hands-on activities can keep the whole class involved in some way."

"I think learning hands on and not in a classroom with people being themselves is the best way to learn and I liked that the most."

"I liked the exercise we did together as a group on an assembly line. It helped everyone to grow comfortable with each other and gave a good perspective on what it was like back then working in the mills. Seeing the machines run was really cool too."

\section{Discussion}

An assessment of the value of this class activity requires an examination of the experience from the point of view of all the participants: students, instructor and the hosting facility. As far as the students were concerned, the goal of the activity was to reach out to different evening styles and to increase learning, retention of concepts and satisfaction. This is the first study to survey VARK learning preferences in an upper level economic class. Even in this context the results confirmed previous findings and indicated the predominance of multimodal learning preferences. Given this background, students' exam performances and survey responses cast some light on the effectiveness of the variety of experiential techniques that was implemented. Students' surveys indicated that both the class discussion and the field trip were useful in facilitating the understanding of A. Smith's chapters. More specifically, they mentioned an improved facility to grasp concepts and to interpret the assigned reading. They enjoyed discovering the concrete applications of what they were studying and the opportunity to work more closely with their peers. The exams scores indicated that those students who had attended the field trip had reached a significantly better grasp of the relevant concepts. The museum visit also permitted them to relate much more easily to several topics that, although not included in the discussion about Adam Smith's chapters, were developed later during the semester (such as the effect of unions, immigration, job safety, or gender on labor market outcomes). On the negative side, they commented on the challenges that any work outside the classroom creates in terms of class and work scheduling, and, in this case, transportation to the field visit site.

Students' feedback illustrate clearly an overall satisfaction with this attempt to combine the reflecting tasks of reading, interpreting and discussing a text with a visual, auditory, and hands-on learning experience. More students responded that they enjoyed the field trip than any other class activity. However, the majority of students also indicated that the guided class discussion was the key activity leading to learning while the role playing exercise was the best suited for remembering what they had learned. This outcome is not surprising, however, given that "students remember half of what they hear and see ... But teach in three sensory modes-- the 
auditory, the visual, and the experiential-- and students remember 97 percent of the material" (Nilson, 2003, p. 86).

The implications of the findings of this study are clearly limited by the fact that they could not be derived through a controlled experiment and through the analysis of knowledge retention over time. They refer to activities that were organized to be in a precise sequence and their order may have affected some of the students' evaluations and comparisons. It is also possible that the findings would not apply to more advanced and theoretical economics classes. However, they confirm the learning benefit of combining different types of experiential activities when facing multimodal learners. They also provide some specific lessons about field trips. These trips must be very clearly framed within well-defined course learning objectives and with objectives that can be easily observed and tested. Field visits can be fun, but having fun is not their primary goal. Students need to perceive them as a rigorous learning activity clearly related to the main focus of the course (Bixler \& Squires, 1998; Smith, 2007). Finally, the value of field trips increases significantly when they include activities that involve directly the students, and when they are followed by a well structured class discussion. These steps will increase their value as tools for learning and for generating long lasting knowledge.

As an instructor, I found this experience very rewarding. It challenged my own ability to see the relevance and applicability of economic texts. It provided me with a unique opportunity to learn from my students and to develop a collegial atmosphere. This paid off during the entire semester because I witnessed students' increased comfort in reaching out to me or to their classmates to ask for help with their coursework. This also lasted in subsequent courses that I taught with some of these same students, including some non-economics majors who decided to enroll in additional economics classes. There were costs associated with this effort, however. The main ones were the time I had to dedicate to developing this class activity and to address logistical issues (see Appendix II: "Recommendations for Field Trips"), and the trade-off I faced in terms of other topics I was not able to cover during the semester because of lack of time.

Finally, the museum personnel also expressed satisfaction with our project. They were glad to have a college class among their visitors. They commented that they enjoyed the challenge of teaching higher education students and that the students' enthusiasm confirmed the value that the personnel attribute to the National Park's mission and to their jobs. They also mentioned that these types of visits are desirable in order to increase their visibility in the community and to strengthen their relationship with the university. It is by demonstrating their ability to deliver this type of public service that such organizations can become more effective in advocating for more public and private funding. Had the visit been to a for-profit entity, it is quite likely that the benefits would have included improved public relationships and proof of their willingness to meet their civic obligations. They would have seen benefits in terms of creating stronger relations with the university as a source of expertise and future potential employees. These kinds of relationships are particularly important to public universities that often have to demonstrate their impact on local communities to justify and advocate for higher public funding. At the same time, it is also undeniable that the hosting institution had to incur some added costs in terms of rearranging rangers' tasks and schedules in order to accommodate my teaching goals and to host my students.

Experiential learning should be evaluated by comparing its costs and benefits to students, universities and community partners (Lawson, 2007). Indeed, my study identifies a variety of costs and benefits occurring to these stakeholders, and the findings suggest that this type of class activity is worthwhile. 


\section{Conclusions}

This paper illustrates an attempt to combine a complex reflective and interpretative learning method (such as reading and guided class discussion of a classical economic text) with a multi-sensory teaching activity (a field trip where students saw and heard new things and were engaged in a hands-on role-playing exercise). This experiential learning session was planned as a result of the increasing awareness of the need for teaching techniques which target different learning styles ${ }^{6}$ including those of students who learn best "by doing." The data collected supports this belief because it showed a prevalence of students with multimodal learning preferences even in upper level economics classes.

This experience was quite successful both in terms of student and teacher satisfaction and learning. This was because the field trip had been carefully planned to better achieve the learning objectives of the class discussion. In particular, the field visit included a role playing/hands on exercise that helped to make the students' learning more long-lasting. It also built a much more collegial class atmosphere that facilitated the work of the instructor during the entire semester.

This paper describes a teaching and learning experience tied to a very specific location but sciences or engineering labs on campuses could provide a valid alternative site visit for this type of class. In addition, almost every community offers a range of potential site visits: new industries, farms, financial institutions, public agencies, legal, health, and other services firms, shelters, living history museums, public projects, conservation land (Lempert, 1996) ${ }^{7}$. The choice should clearly be guided by the focus of the course being taught, by the learning objectives and by the reading material that will be chosen for class discussion.

At a time when universities are facing pressure to reduce costs and to fight competition through the utilization of online teaching and large class sizes (Lawson, 2007), we should carefully weigh the benefits of experiential learning. Better learning and stronger connection with instructors lead to greater student retention. Furthermore, it is by providing long lasting learning for students and forging personal relationships with them that universities can develop loyal alumni/ae and future business partnerships with those graduates who may decide to reach out to their school as a source of future employees or technical and business expertise.

Guided class discussions and field visits, like many other types of experiential learning, involve costs in terms of time, complex scheduling, and direct expenses. Therefore such activities require a supportive university culture where administrators and colleagues are willing to support them and to recognize their learning value.

\section{Acknowledgements}

This paper reflects the work I conducted as a participant in the American Economic Association Teaching Innovation Program (TIP). I would like to thank Michael Salemi who supervised my work while I was developing a "discussion module" for the program. Diana Archibald and Robin Toof also helped me with useful comments about experiential learning and community-university partnership. Michael DiNardi and Sushmita Subedi provided excellent

\footnotetext{
${ }^{6}$ The need to explore a variety of teaching methods is likely to increase as more students with learning, physical, and mental disabilities are entering higher education (Whinnery, 1992; Vickers, 2010).

${ }^{7}$ Mark Smith lists a variety of field trips destination for classes in environmental economics on his web site http://coloradocollege.edu/dept/EC/Smith/fieldtripmaterials/Field_Trip_Case_Studies.doc
} 
teaching assistantship. Priscilla March assisted me with the VARK questionnaire. I am also very grateful to Sheila Kirschbaum, Interim Director of the Tsongas Industrial History Center, and the rangers of the Lowell National Historical Park who assisted my students and me during the Boott Cotton Mills Museum visit.

\section{Appendices}

Appendix I: Questions about Adam Smith's Chapters 1-3

\begin{tabular}{|c|c|}
\hline \multicolumn{2}{|r|}{ Learning Objectives } \\
\hline $\begin{array}{l}\text { a. Students sh } \\
\text { opportunity } \\
\text { b. Students sh } \\
\text { of a place a } \\
\text { c. Students sh } \\
\text { of labor is } 1\end{array}$ & $\begin{array}{l}\text { d be able to explain why the division of labor results from the desire and } \\
\text { trade. } \\
\text { d be able to explain how the demographic and geographic characteristics } \\
\text { t the inhabitants' ability to trade. } \\
\text { d be able to explain why causality between new technologies and division } \\
\text { necessarily unidirectional. }\end{array}$ \\
\hline \multicolumn{2}{|r|}{ Questions for in Class Discussion } \\
\hline $\begin{array}{l}\text { Basic interpretive } \\
\text { question }\end{array}$ & $\begin{array}{l}\text { Recall what you observed last week during our visit at the Boott Cotton } \\
\text { Mills Museum. Now think about the three chapters of Smith's The Wealth } \\
\text { of Nations. How would have Smith explained the rise of the Mills, the use } \\
\text { they made of labor, and their success? }\end{array}$ \\
\hline $\begin{array}{l}\text { Supporting } \\
\text { questions }\end{array}$ & $\begin{array}{l}\text { a. How, according to Smith, is the division of labor affected by } \\
\text { specific firms' characteristics (such as size, sector, etc.)? } \\
\text { b. According to Smith, what is the relationship between } \\
\text { "inventions" and division of labor? } \\
\text { c. How, according to Smith, does the division of labor differ } \\
\text { between intellectual and manual labor? } \\
\text { d. According to Smith, how do the opportunities to trade affect "the } \\
\text { difference of talents" among individuals? } \\
\text { e. How do you think Smith would have classified the Merrimack } \\
\text { River in Lowell? Along with the Rhine and the Ganges or along } \\
\text { with the African and Siberian rivers? Why? }\end{array}$ \\
\hline $\begin{array}{l}\text { Concluding } \\
\text { questions }\end{array}$ & $\begin{array}{l}\text { a. Imagine that Adam Smith had lived fifty more years and had had } \\
\text { the chance to visit Lowell and the Mills in the 1820s. How would } \\
\text { he have revised the three chapters you read? } \\
\text { b. What is a possible implication of the division of labor on } \\
\text { economies of scale and therefore on firms' market power? } \\
\text { c. To what extent is Smith's explanation of the division of labor } \\
\text { challenged by the new information economy? }\end{array}$ \\
\hline \multicolumn{2}{|r|}{ Exam Question } \\
\hline \multicolumn{2}{|c|}{$\begin{array}{l}\text { Suppose Adam Smith observed that there was a division of labor in production in economy A but } \\
\text { not in economy B. Based on the first three chapters of The Wealth of Nations, how would Smith } \\
\text { explain the difference? }\end{array}$} \\
\hline
\end{tabular}

Journal of the Scholarship of Teaching and Learning, Vol. 14, No. 5, December 2014. 


\section{Appendix II: Recommendations for Conducting Field Visits}

1. Frame the experience very clearly within well-defined course learning objectives with objectives that can be easily observed and tested. Field visits can be fun, but having fun is not their primary goal. Students need to perceive them as a rigorous learning activity clearly related to the main focus of the course (Bixler and Squires 1998, Smith 2007).

2. Share your students' background and learning objectives with your hosting institution so that local facilitators may prepare and help you achieving your teaching goals (Smith 2008).

3. Assess carefully whether the class size will be conducive to a successful field trip experience and to a meaningful role playing exercise (in my opinion, for this type of activities, a class should not include more than 25 students). It is difficult to organize and effectively monitor the work of a large group of students outside the classroom.

4. Plan and organize the field visit way ahead of time, at the latest during the previous semester. This will allow for including the date in the syllabus distributed on the first day of class so that working students can make arrangements right away so that they can participate. It will also allow time to approach the administration to ask for coverage of any monetary costs that the trip may entail and to contact early on those colleagues whose classes could be affected by the students' participation in the field trip.

5. Schedule classes either early or late in the day so that potential field visits will minimize conflicts with classes taught by other colleagues.

6. Consider and address in advance the logistics problems associated with students' transportation to the site of the field visit.

7. Explain to your students that they are becoming your school "ambassadors" and that, as such, they are expected to show proper behaviors.

8. Manage the risk associated with activities occurring outside the classroom: assess carefully the risks that the outside activity and experiential learning may create for the students and for the host companies or organizations. For example, liabilities can arise because of off-campus injuries, because students may damage a host site's equipment, or because the visited site is not accessible to a disabled student (Gallagher 2008). Check the university's travel guidelines and, at the minimum, have the students file an "authorization to travel" form and a "waiver of liability" form. 


\section{References}

Bhadra, L. J. (2006). A picture is worth a thousand words: Engaging kinesthetic and multimodal learners of economics using contemporary films. Inquiry, 11 (1), 11-19.

Bhaskar, S. (2011). Implications of perceptual learning style preferences on management pedagogy. International Journal of Research in Commerce and Management, 2, 109-114.

Bixler, V. J., \& Squires, J. R. (1998). Enhancing the field experience in financial education. Financial Practice \& Education, 8 (2), 83-87.

Boatman, K., Courtney, R., \& Lee, W. (2008). "See how they learn:" The impact of faculty and student learning styles on student performance in introductory economics. American Economist 52 (1): 39-48.

Borg, M. O., \& Stranahan, H. A. (2002). Personality type and student performance in upper-level economics courses: The importance of race and gender. The Journal of Economic Education, 33 (1), 3-14. doi: 10.1080/00220480209596120

Charkins, R. J., O'Toole, D. M., \& Wetzel, J. N. (1985). Linking teacher and student learning styles with student achievement and attitudes. The Journal of Economic Education, 16 (2), 111120. doi: 10.1080/00220485.1985.10845106

Dickie, M. (2006). Do classroom experiments increase learning in introductory microeconomics? Journal of Economic Education, 37, 267-288. doi: 10.3200/JECE.37.3.267-288

Durham, Y., McKinnon T., \& Schulman, C. (2007). Classroom experiments: Not just fun and games. Economic Inquiry, 45,162-178. doi: 10.1111/j.1465-7295.2006.00003.x

Emerson, T. L. N., \& Taylor, B. A. (2007). Interactions between personality type and the experimental methods. Journal of Economic Education, 38, 18-35. doi: 10.3200/JECE.38.1.1835

Emerson, T. L. N., \&Taylor, B. A. (2004). Comparing student achievement across experimental and lecture-oriented sections of a principles of microeconomics course. Southern Economic Journal, 70, 672-93. doi: 10.2307/4135338

Fitkov-Norris, E., \& Yeghiazarian, A. (2013). Assessing the learning style preferences of postgraduate general business management students using VARK. European Conference on Research Methodology for Business and Management Studies, 144-XIII. Kidmore End: Academic Conferences International Limited.

Fleming, N. D., \& Mills, C. (1992). Not another inventory, rather a catalyst for reflection. To Improve the Academy, 11,137-155. 
Gallagher, A. J., \& Co. (2008). Beyond the classroom. Experiential learning: Managing risks Maximizing rewards. Retrieved from:

http://www.ajgrms.com/portal/server.pt/gateway/PTARGS_0_28406_558233_0_0_18/Beyond\% 20the\%20Classroom\%20-\%20Experiential\%20Learning.pdf.

Garces-Ozanne, A., \& Esplin P., (2010). To work or not to work . . . that is the question: Labour market decisions in the classroom. International Review of Economics Education, 9, 84-98.

Gibson, A. (2010). Measuring business student satisfaction: A review and summary of the major predictors. Journal of Higher Education Policy \& Management, 32, 251-259. doi:

$10.1080 / 13600801003743349$

Hansen, W. L., \& Salemi, M. K. (1998). Improving classroom discussion in economic courses in teaching undergraduate economics. In W. Walstad \& P. Saunders (Eds.), A handbookfor instructors. New York: Irwin/McGraw-Hill.

Harmon, O. R, Alpert, W., \& Histen, J. (2014). Online discussion and learning outcomes. International Advances in Economic Research, 20 (1), 33-44. doi: 10.1007/s11294-013-9453-9

Hawk, T. F., \& Shah, A. J. (2007). Using learning instruments to enhance student learning. Decision Sciences Journal of Innovative Education, 5(1), 1-19. doi: 10.1111/j.15404609.2007.00125.x

Hawtrey, K. (2007). Using experiential learning techniques. The Journal of Economic Education, 38 (2), 143-152. doi: 10.3200/JECE.38.2.143-152

Kolb, D.A. (1984). Experiential learning: Experience as the source of learning and development. Englewood Cliffs, NJ: Prentice Hall.

Jensen, E. J., \& Owen A. L. (2003). Appealing to good students in introductory economics, Journal of Economic Education, 34, 299-325. doi: 10.1080/00220480309595225

Lawson, L.L. (2007). The economics of experience-based higher education. Atlantic Economic Journal, 35 (1), 23-31. doi: 10.1007/s11293-006-9047-5

Lempert, D. H., \& Briggs, X. (1996). Escape from the Ivory Tower: Student adventures in democratic experiential education. San Francisco: Jossey-Bass Publishers.

Leung, A., McGregor, M., Sabiston, D., \& Vriliotis, S. (2014). VARK Learning styles and student performance in principles of micro- vs. macro-economics. Journal of Economics and Economic Education Research, forthcoming.

Lopus, J., \& Hoff, J. (2009). Is there a disconnect between teaching styles and learning styles in high school economics classes? Journal of Private Enterprise, 24 (2), 157-164. 
Madden, K. K. (2010). Engaged learning with the inquiry-based question cluster discussion technique: Student outcomes in a history of economic thought course. Southern Economic Journal, 77 (1), 224-239. doi: 10.4284/sej.2010.77.1.224

Meltzoff, A. N., Kuhl, P. K., Movellan, J. \& Sejnowski, T. J. (2009). Foundations for a new science of learning. Science, 325, 284-288. doi: 10.1126/science.1175626

Mutiu, A., \& Moldovan, G. (2011). How to better meet our students' learning styles through the course resources. Annals of the University of Oradea: Economic Science, 2, 578-584.

Nilson, L. B. (2003). Teaching at its best: A research-based resource for college instructors (2nd ed.). Bolton, MA: Anker Pub. Co.

Pashler, H., McDaniel, M., Rohrer, D., \& Bjork, R. (2008). Learning styles: Concepts and evidence. Psychological Science in the Public Interest, 9, 105-119.

Salemi, M. (2005). Asking the right kind of question promotes learning during discussion. Retrieved from: http://www.unc.edu/ salemi/Papers/Asking_Right_Kind_of_Question.pdf.

Salemi, M. (2002). An illustrated case for active learning. Southern Economic Journal, 68 (3). 721-731. doi: 10.2307/1061730

Smith, M. G. (Summer, 2007). Case studies on location: Taking to field in economics. Journal of Economic Education, 308-317. doi: 10.3200/JECE.38.3.308-317

Smith, R., \& O'Connell, P. (Winter, 1997). Workers on the line: Teaching industrial history at the Tsongas Industrial History Center and Lowell National Historical Park. OAH Magazine of History, 22-26.

Spencer, R. W., \& Van, D. F. (1986). Experiential learning in economics. The Journal of Economic Education, 17 (4), 289-294. doi: 10.1080/00220485.1986.10845175

Tsongas Industrial History Center. (2011). Activity Guide. Workers on the Line. University of Massachusetts Lowell Graduate School of Education, Lowell National Historical Park. Retrieved from: http://www.uml.edu/tsongas/Curriculum_Materials/Curriculum_Packets/WOL.pdf.

Vickers, M. Z. (2010). Accommodating college students with learning disabilities: ADD, ADHD, and Dyslexia. John W. Pope Center for Higher Education Policy. Retrieved from: http://www.popecenter.org/acrobat/vickers-mar2010.pdf.

Watts, M., \& Becker, W. E. (Summer, 2008). A little more than chalk and talk: Results from a third national survey of teaching methods in undergraduate economics courses. Journal of Economic Education, 273-286. doi: 10.3200/JECE.39.3.273-286 
Galizzi, M.

Wetzel, J. N., O'Toole D., \& Peterson, S. (1999). Factors affecting student retention probabilities: A case study. Journal of Economics and Finance, 23, 45-55. doi:

10.1007/BF02752686

Whinnery, K. W. (1992). College preparation for students with learning disabilities: A curriculum approach. Preventing School Failure, 37 (1), 31-34. doi:

10.1080/1045988X.1992.9944593

Journal of the Scholarship of Teaching and Learning, Vol. 14, No. 5, December 2014. 